\title{
DESENHO DE PAISAGEM URBANA: AS CIDADES MÉDIAS DO INTERIOR CENTRAL PAULISTA
}

Paula da Cruz Landim

Arquiteta pela Faculdade de Arquitetura e Urbanismo da USP, mestre em geografia pelo Instituto de Geociências e Ciências Exatas da Unesp - Rio Claro, doutora em arquitetura pela Faculdade de Arquitetura e Urbanismo da USP, professora da Faculdade de Arquitetura, Artes e Comunicação da Unesp - Bauru.

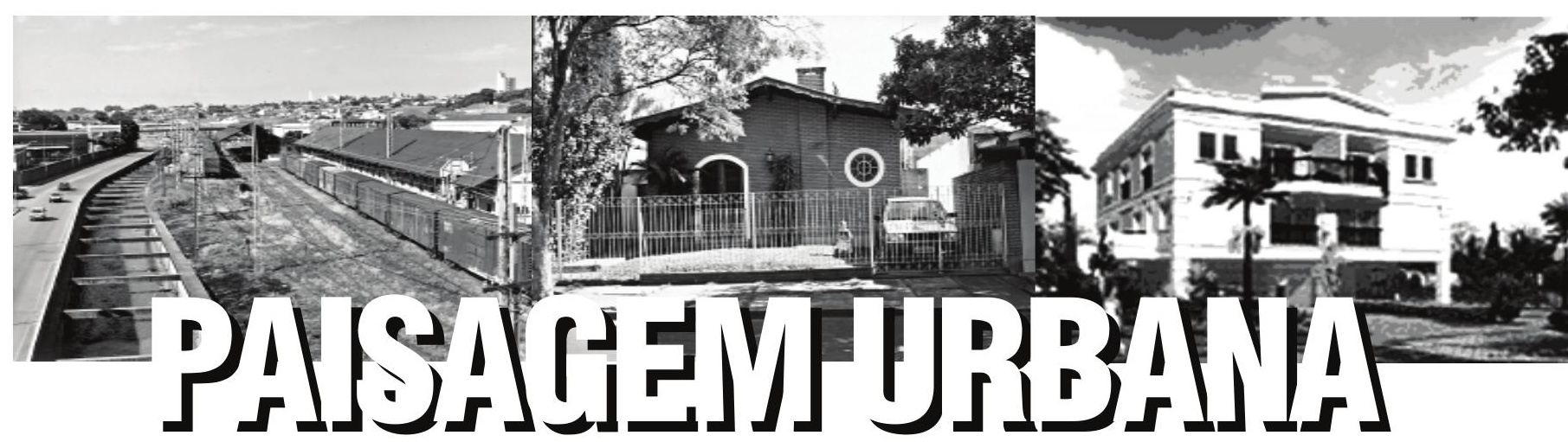




\section{RESUMO}

Este trabalho focaliza a homogeneidade da paisagem urbana das cidades de porte médio do interior do estado de São Paulo do ponto de vista de seus determinantes paisagísticos. A origem socioeconômica das cidades determina, em um primeiro momento, sua configuração, a qual, esgotado o estímulo inicial, passa a incorporar as imagens formais das grandes cidades. Estas imagens estão claramente representadas de um modo específico na paisagem urbana dessas cidades, evidenciando os reflexos formais e funcionais das paisagens dos grandes centros, e na geração de valores estéticos e de uso do espaço relacionados aos aspectos formais e visuais que se fazem presentes em suas paisagens. A legislação que define os padrões de ocupação urbana, os quais por sua vez definem a configuração física da paisagem, trabalha basicamente o espaço físico-territorial, alienando-se dos demais componentes da problemática urbana, e, desta forma, as cidades se homogeneízam. Ou seja, gera um discurso urbanístico pobre e o que se faz é generalista. A paisagem da cidade média paulista é então homogênea como conseqüência desta forma de ocupação homogênea. Como contraposição à paisagem homogênea, algumas condições ambientais e paisagísticas locais, como a presença de um rio ou de uma topografia acidentada, servem de início como determinantes para projetos urbanísticos/paisagísticos diferenciados e característicos para cada cidade, mas no momento seguinte os elementos da "moda" entram na composição da paisagem, descaracterizando o padrão diferenciado inicial.

\section{ABSTRACT}

This work focuses the homogeneity of the urban landscape of the cities of medium size in the countryside of the state of São Paulo. The formal images of the great cities are represented in a specific way in the urban landscape of the medium cities, evidenciating the formal and functional reflexes of the landscapes of the great centres over the landscape of the cities of the countryside, generating values related to its formal and visual aspects. The morphologic structure of these cities is homogeneous due to the reflexes of the socio-cultural dominant patterns present in the landscapes of the centres with larger socio-economic influence, that generate aesthetic values for the urban space use related to the formal and visual aspects present in its landscapes. The landscape of the medium city from São Paulo state is then homogeneous as a consequence of this form of homogeneous occupation, which is due to the standardized codes of work and managing plans, as well as to similar cycles of development, what results in uniform urbanization patterns, associated to the similar architectural and used material typologies. In opposition to the homogeneous landscape, the development of aesthetic values starting from environmental conditions and local characteristics can be useful as good tools for making differentiated urbanistic/landscape projects proper for each city. 


\section{DESENHO DE PAISAGEM URBANA: AS CIDADES MÉDIAS DO INTERIOR CENTRAL PAULISTA}

As cidades de Bauru, Jaú, São Carlos localizadas no Planalto Ocidental, e Limeira, Piracicaba e São Carlos na depressão periférica são o objeto deste estudo. Nestas cidades se observou a maneira como suas paisagens se formalizam e se organizam, pela análise de suas configurações, identificando quais foram os agentes homogeneizadores, e verificando como a paisagem se estruturou a partir destes elementos. A análise da estrutura morfológica dessas cidades permite montar um quadro claro desta similaridade/especificidade.

Pode-se observar como as paisagens se formalizam e se organizam, por meio da leitura das configurações urbanas, identificando quais seriam os agentes homogeneizadores, e verificando como a paisagem se estrutura a partir destes elementos.

A homogeneidade dos padrões morfológicos urbanos no interior paulista está ligada a ciclos de desenvolvimento semelhantes, tais como a expansão cafeeira e o conseqüente incremento da rede ferroviária, e depois rodoviária, que imprimiram às cidades um padrão de urbanização bastante similar.

A princípio a arquitetura edificada sobre os lotes é bastante convencional e simples, constituindo-se em um casario baixo e térreo, nos primeiros tempos da urbanização e assobradado nos anos de 1980 e 1990, fornecendo uma configuração de paisagem urbana homogênea. A rua é o espaço livre inicial, constituído por parcelamento e construções similares, formando calhas, que se repetem.

Nas cidades analisadas, na maioria dos casos, a topografia, geralmente, não apresenta características suficientemente marcantes para constituir paisagens diferenciadas, e, paralelamente, a legislação sempre reforçou a homogeneidade, ao mesmo tempo em que a similaridade nas formas de apropriação e parcelamento do solo retroalimentam o processo. 
Os padrões homogêneos estão, então, basicamente relacionados ao papel da legislação, ao parcelamento do solo, ao sítio e ao suporte físico.

A legislação urbanística fortalece e/ou direciona a estrutura similar de paisagem, e representa a possibilidade oficial de manutenção, reforço, ou ainda destruição da paisagem, pois segundo Macedo (1998):

"um outro caso, de aplicação indiscriminada de um modelo se deu na definição das leis orgânicas municipais, também nos pequenos municípios, que em muitos casos são meras cópias de 'cartilhas', sem nenhuma consideração com a identidade social, ambiental e paisagística do município". (p. 79)

Os padrões morfológicos fornecem um modelo de paisagem, ao qual está ligado um modelo de qualidade de vida, no qual a sociedade passa a valorizar a presença dos elementos morfológicos globais que estão em sintonia com os centros de poder. Novamente segundo Macedo (1995, p. 50), "os padrões de organização espacial dos mais ricos, paradoxalmente, são reproduzidos, como todos os demais, típicos das elites sociais, de um modo reduzido, e na medida possivel por todas as camadas sociais".

Estes elementos e a sua organização, em pouco diferem, em termos de representação e significado, daqueles encontrados em paisagens representativas de outros momentos históricos, que igualmente se constituíam em modelos. Os elementos que conferem legibilidade ao espaço urbano são os mesmos, mas a leitura é diferente.

Para a população, o que muitos consideram como estruturas exógenas à paisagem local substituída, como os prédios de apartamento ou o shopping, são justamente aqueles elementos que conferem um sentido de modernidade à sua cidade.

Dois fatores são fundamentais para justificar tais configurações e posturas: a velocidade com que as estruturas originais são substituídas por outras, e a disponibilidade tecnológica, que permite a reprodução fiel de estruturas e formas exógenas, na qual os processos e materiais não mais ilustram as características e recursos locais.

As cidades do interior central paulista, ao final do século 20, caracterizam-se por se situarem em áreas praticamente planas, como ilustra a Figura 1, apenas com leves ondulações, cortadas por rios ou não, observado na Figura 2, pela ferrovia, como é o caso da Figura 3 , e/ou por grandes eixos rodoviários, presente no exemplo da 
Figura 1 - Limeira, SP Crédito: Autora

Figura 2 - Piracicaba, SP Crédito: Autora

Figura 3 - Limeira, SP Crédito: Autora
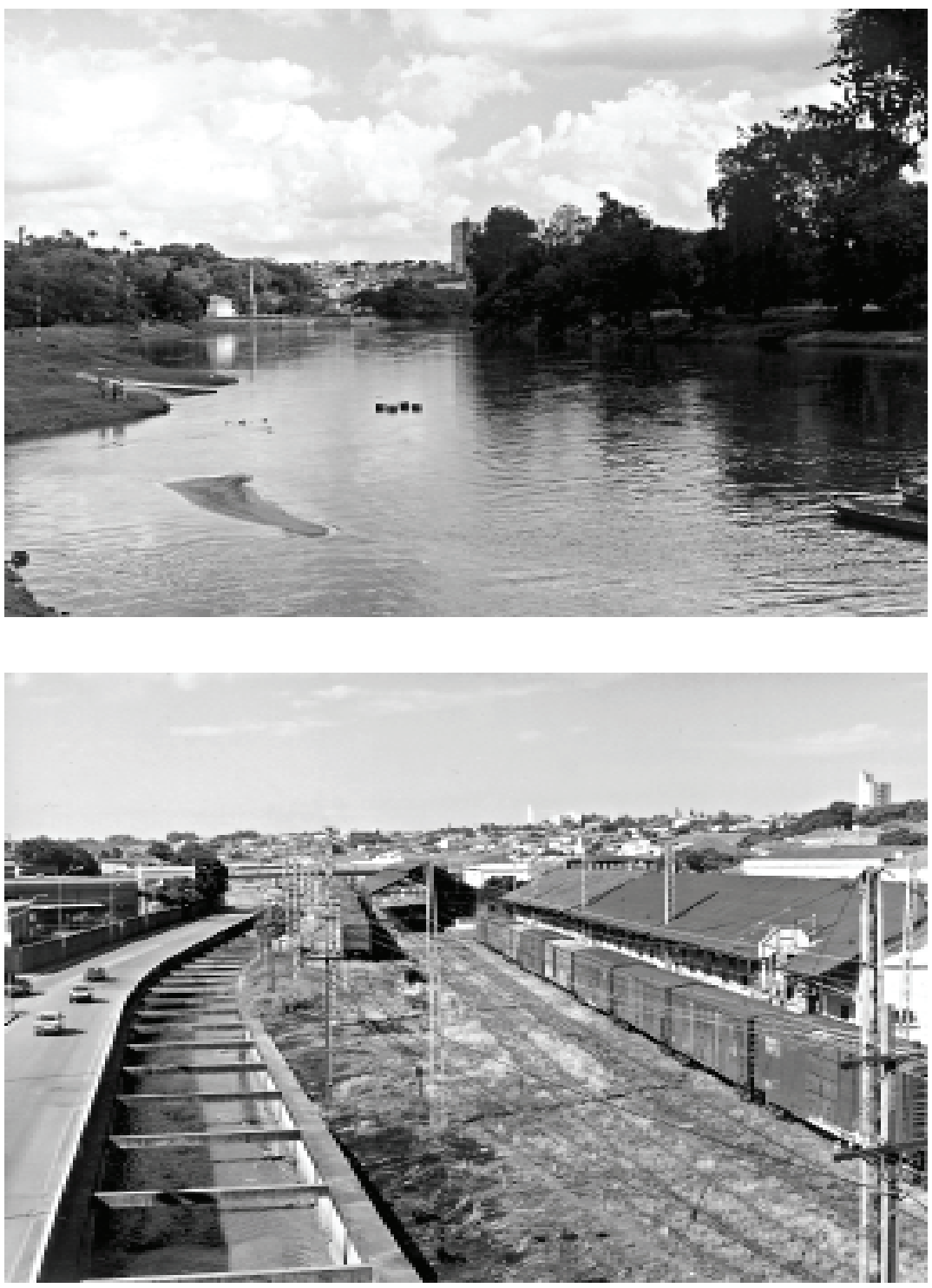


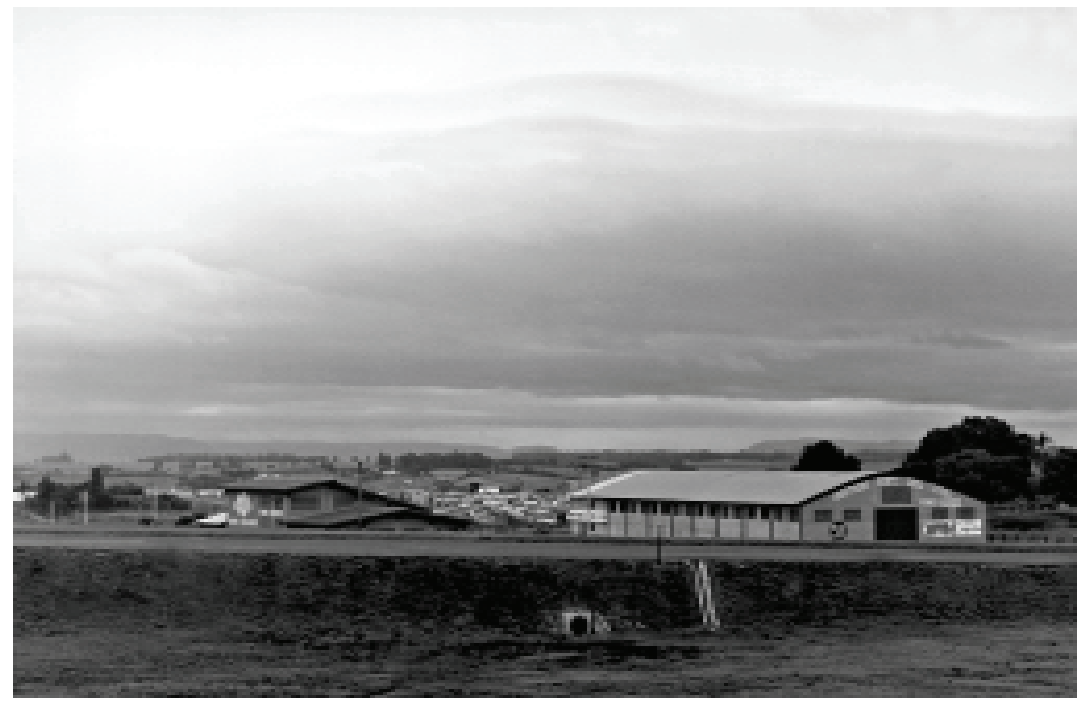

Figura 4 - Rio Claro, SP Crédito: Autora

Figura 4 , sendo que estas barreiras, naturais ou construídas já foram, em sua maioria, ultrapassadas pelo crescimento da mancha urbana.

São cidades horizontais em sua maioria, onde a verticalização é pontual ou restringe-se à área central, e com significativa arborização urbana.

Estas cidades tendem a crescer ao longo da barreira, seja ela qual for, sendo que, em geral, os bairros populares se localizam além da barreira, e os da classe mais abastada do mesmo lado do centro. Esta área central, geralmente, está próxima à ferrovia ou à antiga ferrovia e distante das rodovias.

Os bairros residenciais das elites normalmente ocupam os melhores lugares, refletindo seus valores sociais, as exigências de condições de segurança, salubridade e beleza, que variam no contexto de cada situação histórica, atendido prioritariamente o requisito da acessibilidade, ilustrado nos exemplos das Figuras 5A e 5B.

Nas cidades médias, para as camadas de alta renda é atribuída uma infra-estrutura urbana no setor por ela ocupado, passando a haver uma certa segregação dos usos do solo em áreas específicas.

As camadas populares ocupam os resíduos do espaço urbano, ou também áreas distantes, contribuindo para a especulação imobiliária. E, tendo como mercado de trabalho a indústria, o setor terciário, ou o subemprego, passam a habitar perto dos locais de trabalho.

Nos bairros mais antigos e centrais, as construções são alinhadas na via pública e nas divisas do lote, sendo que se observa uma monoto- 
Figura 5A - Rio Claro, SP Crédito: Autora

Figura 5B-Bauru, SP Crédito: Autora
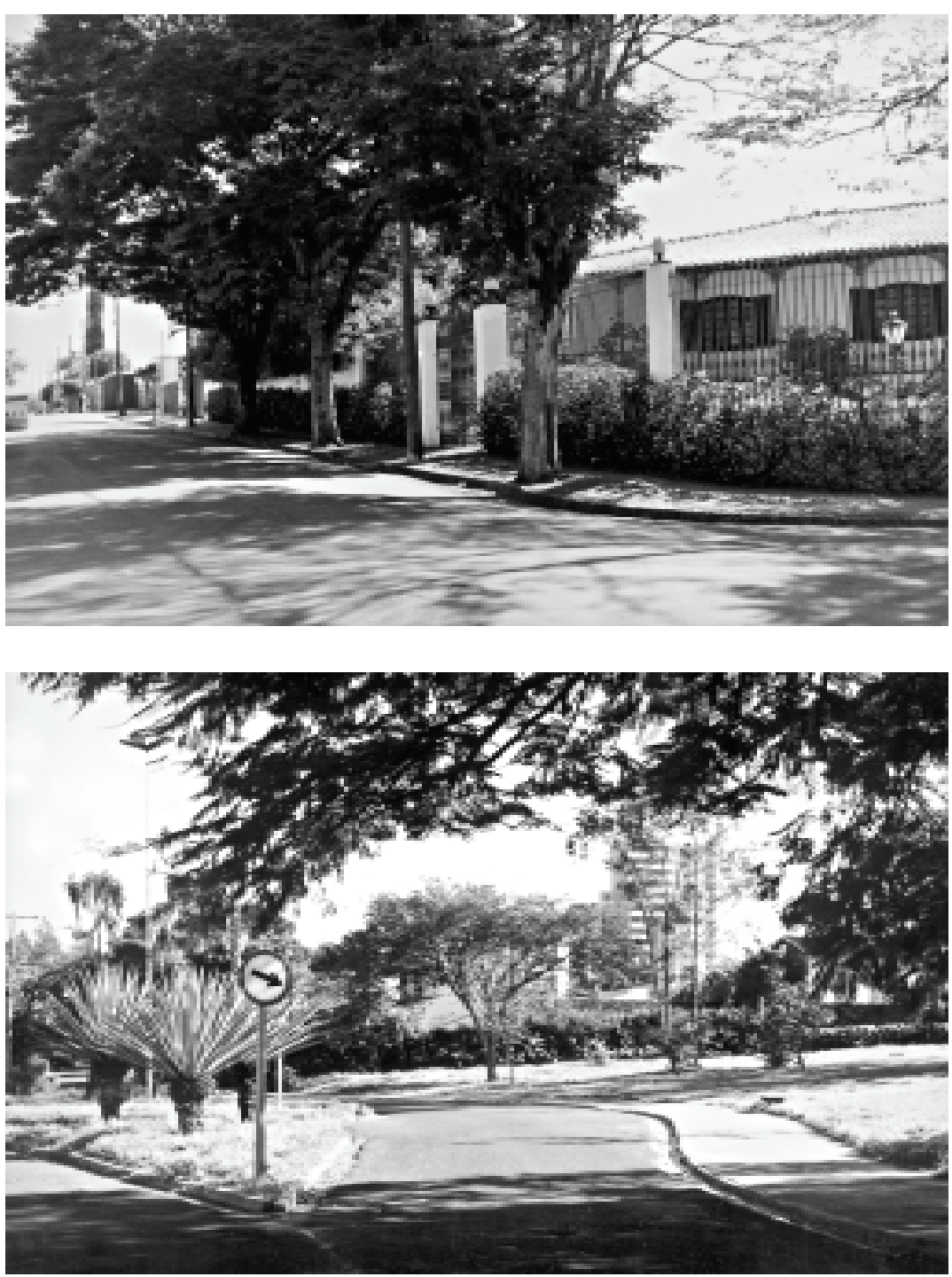

nia construtiva muito grande nas fachadas, que só raramente é quebrada pelos materiais e/ou pelas cores utilizadas, exemplificado nas Figuras 6A e 6B.

Nos bairros mais novos encontram-se casas com gabaritos diferentes, algumas com recuo frontal e/ou lateral, obedecendo aos recuos permitidos em cada bairro, como está ilustrado nas Figuras de 7A até 7D.

A organização básica e homogênea das periferias formais da cidade média está calcada principalmente na legislação municipal de loteamento e uso do solo, que reflete os interesses de incorporadores e dos proprietários do solo urbano, ou seja, vai refletir o interesse dos grandes proprietários de glebas de terra adquiridas em áreas distan- 


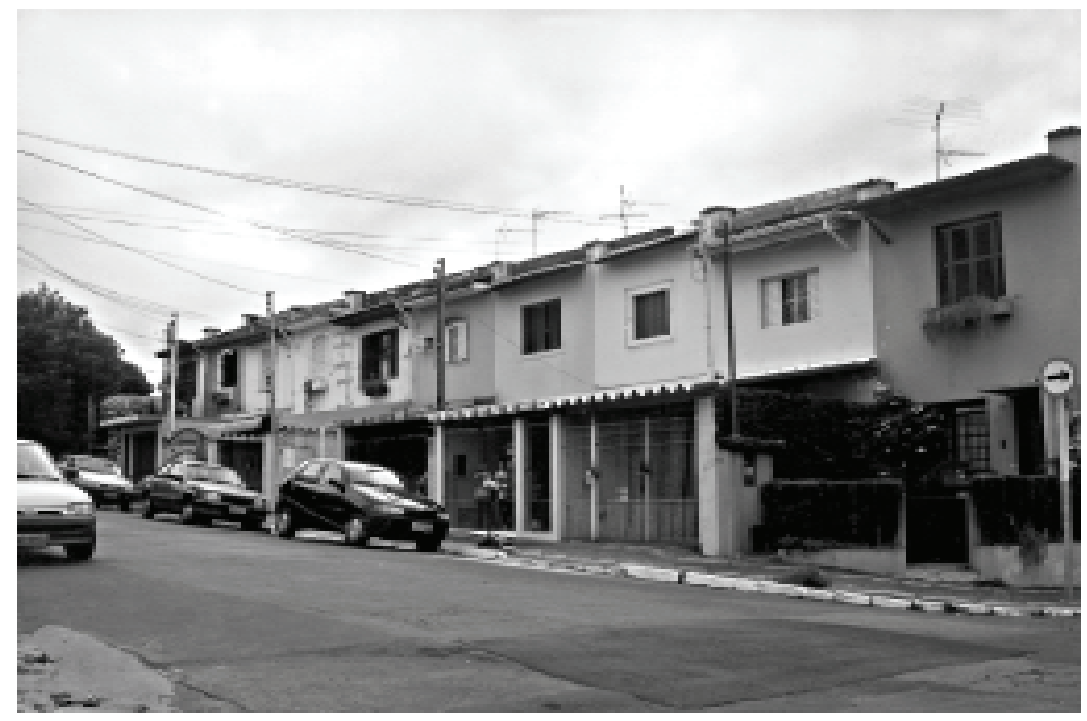

Figura 6A - Limeira, SP

Crédito: Autora

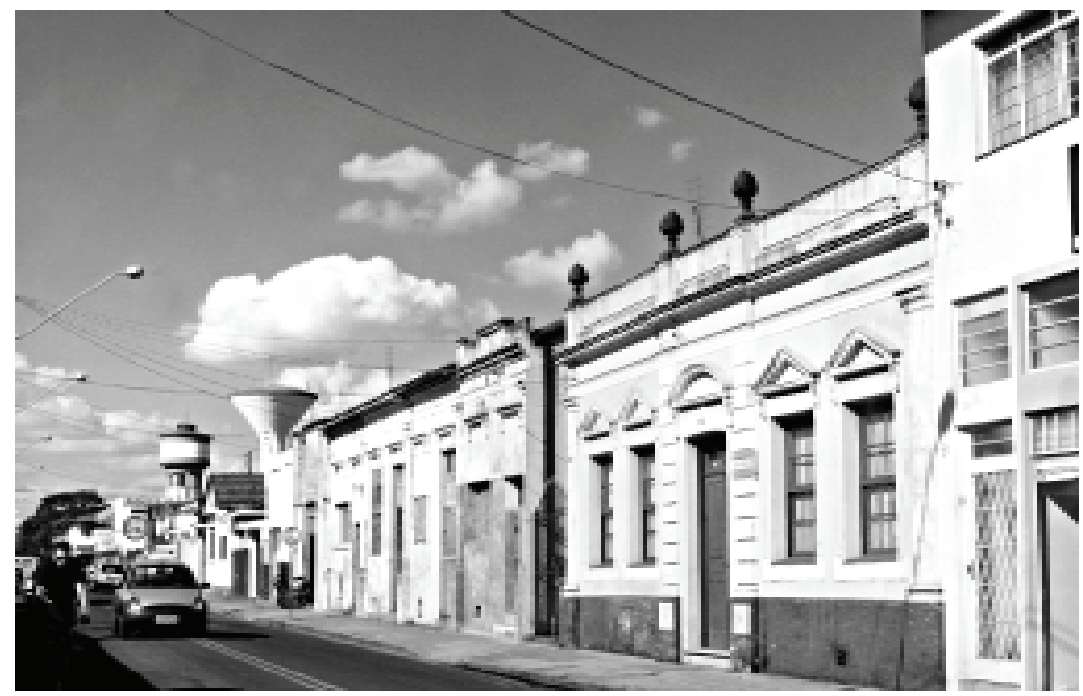

Figura 6B - Rio Claro, SP

Crédito: Autora

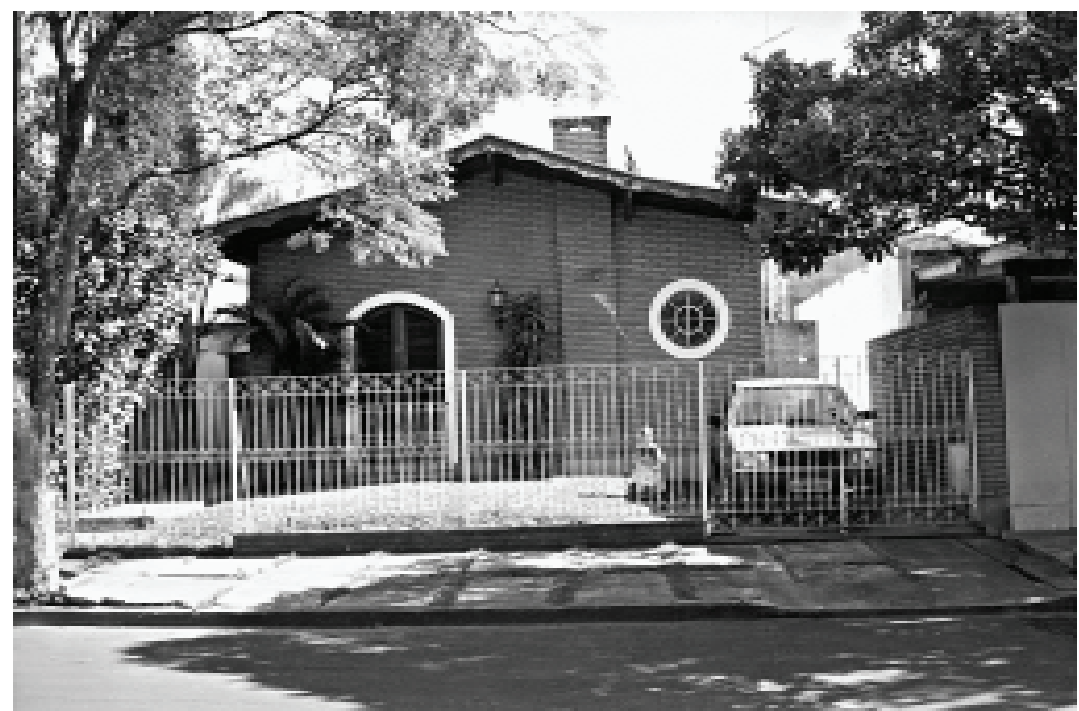

Figura 7A - São Carlos, SP Crédito: Autora

Paisagem Ambiente: ensaios - n. 16 - São Paulo - p. $109-133-2002$ 
Figura 7B - Limeira, SP Crédito: Autora

Figura 7C-Bauru, SP Crédito: Autora

Figura 7D - Jaú, SP Crédito: Autora
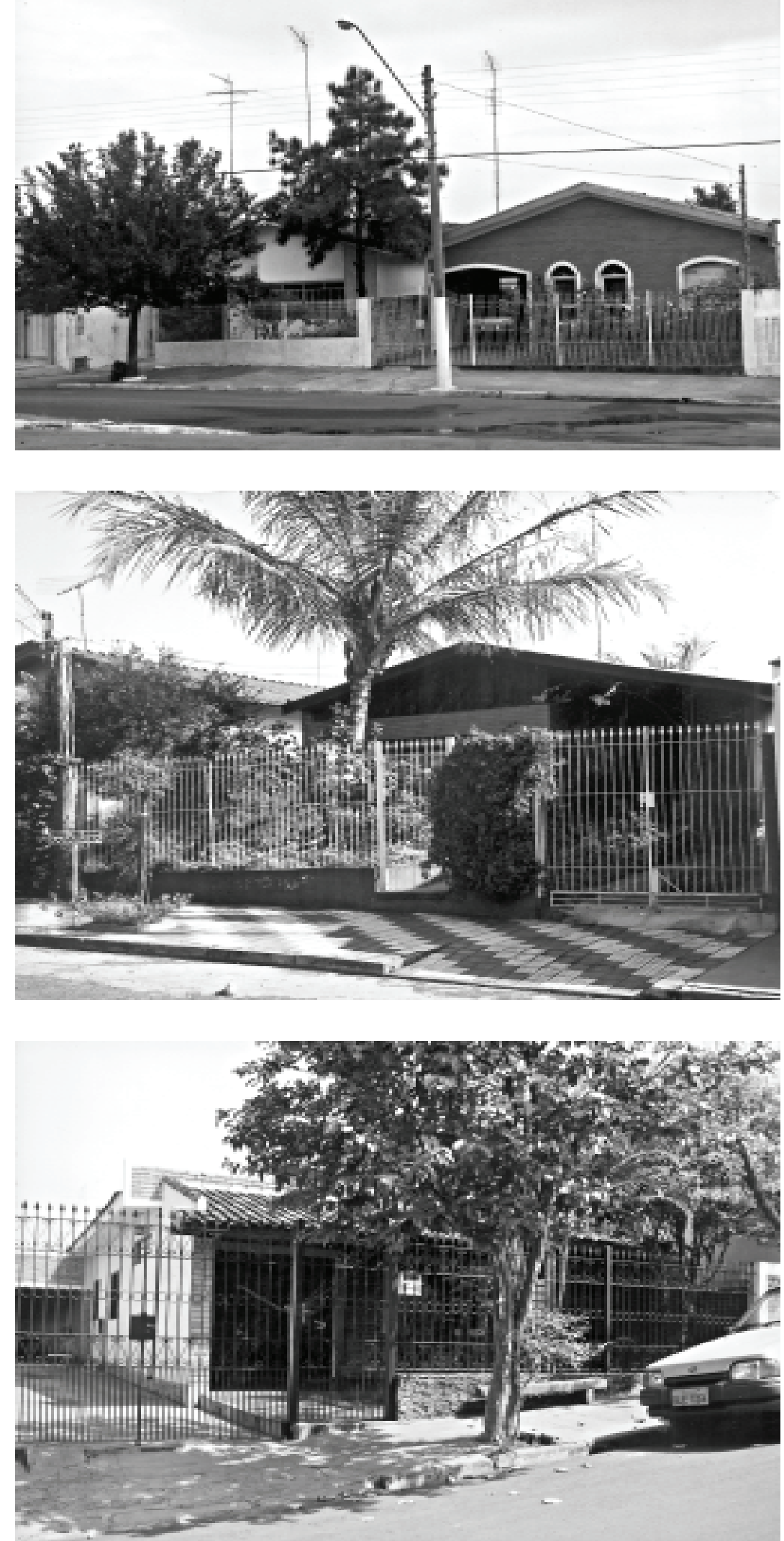

117 
tes do centro, tendo em vista a futura especulação imobiliária. Em função do crescimento urbano, estas porções de terra são transformadas em loteamentos residenciais dos mais variados tipos, ou ainda desapropriadas por parte do poder público municipal para construção dos conjuntos habitacionais e distritos industriais, sendo que a configuração final é fornecida pelo mercado imobiliário, que vai determinar, com a instalação de seus empreendimentos, os elementos formais da paisagem urbana.

As formas urbanas são decorrências, nessas cidades, de códigos de obras e planos diretores bastante semelhantes, que vão determinar as larguras das vias e calçadas, altura das edificações, recuos nos lotes, localização de praças e afins, locação de terminais de carga, rodoviá-
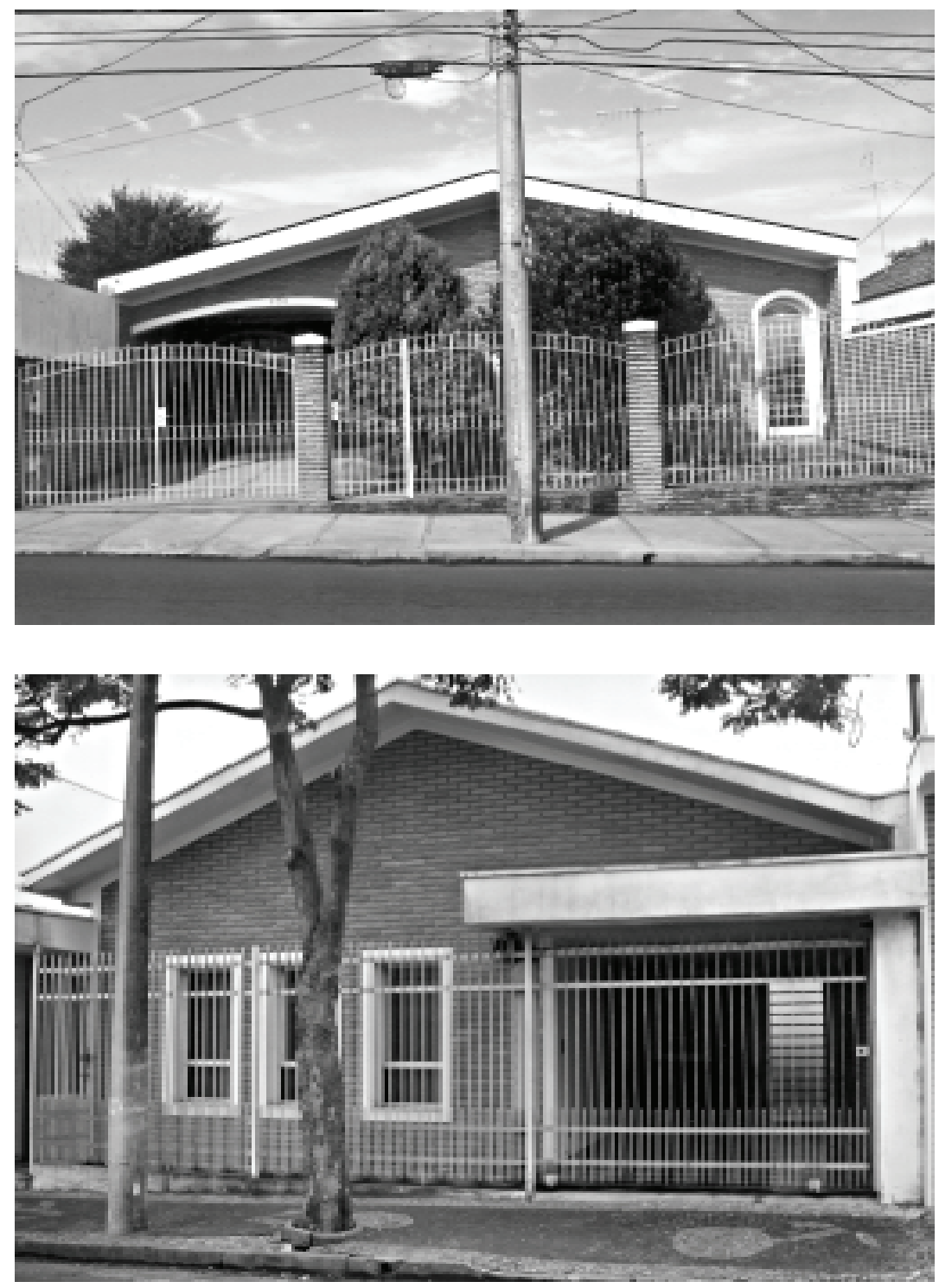

Figura 8B - Limeira, SP Crédito: Autora
Figura 8A - São Carlos, SP Crédito: Autora 
rias, distritos industriais e aeroportos entre outros, partindo de um ideal comum, determinado pelo mercado imobiliário, os quais foram criados para regulamentar a espontaneidade do crescimento original das cidades, gerando assim, novamente, paisagens homogêneas.

Associadas às formas de ocupação urbana semelhantes, encontramse as mesmas formas de tipologias arquitetônicas, as quais se associam também a utilização de material de acabamento comum. Estes elementos ordinários, pertencentes ao repertório formal da grande maioria da população, principalmente no que se refere às moradias, geram soluções espaciais e volumétricas que dão forma à cidade, o que as homogeneíza, conforme está ilustrado nas Figuras de $8 \mathrm{~A}$ até $8 \mathrm{D}$.

Figura $8 \mathrm{C}$ - Piracicaba, SP Crédito: Autora

Figura 8D - Bauru, SP Crédito: Autora
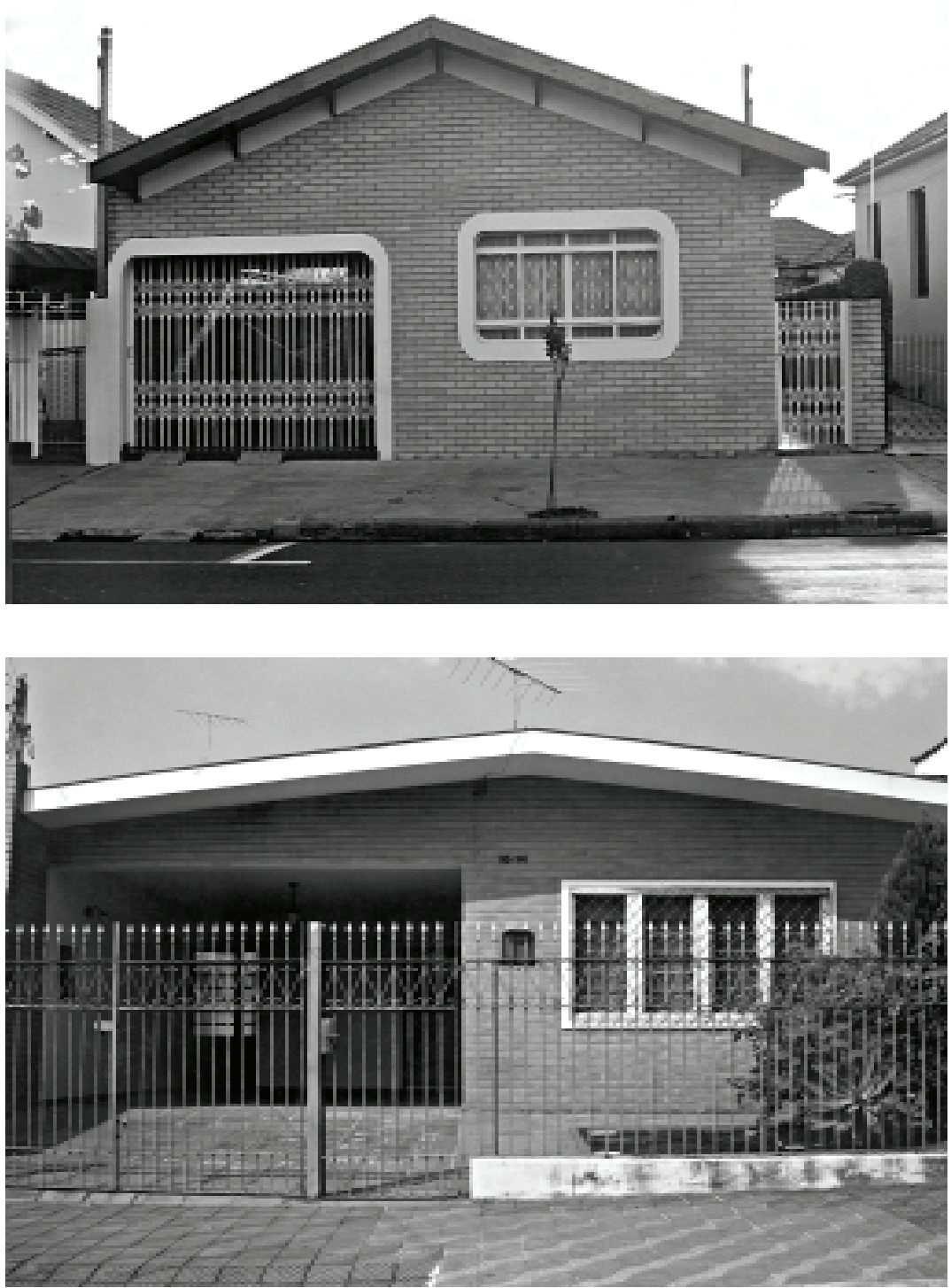
A partir da configuração morfológica e espacial anteriormente descrita, identificam-se os tipos de tecidos urbanos e de elementos construídos.

Estes padrões morfológicos são identificados na maioria dos conjuntos urbanos de médio porte do interior central paulista, sendo que a espacialização destes padrões obedece a uma lógica similar que se baseia em antecedentes comuns de formação urbana.

Pode-se então construir uma "paisagem padrão", uma imagem destas cidades por meio de uma representação hipotética, como se observa na figura $8 \mathrm{E}$, a seguir.

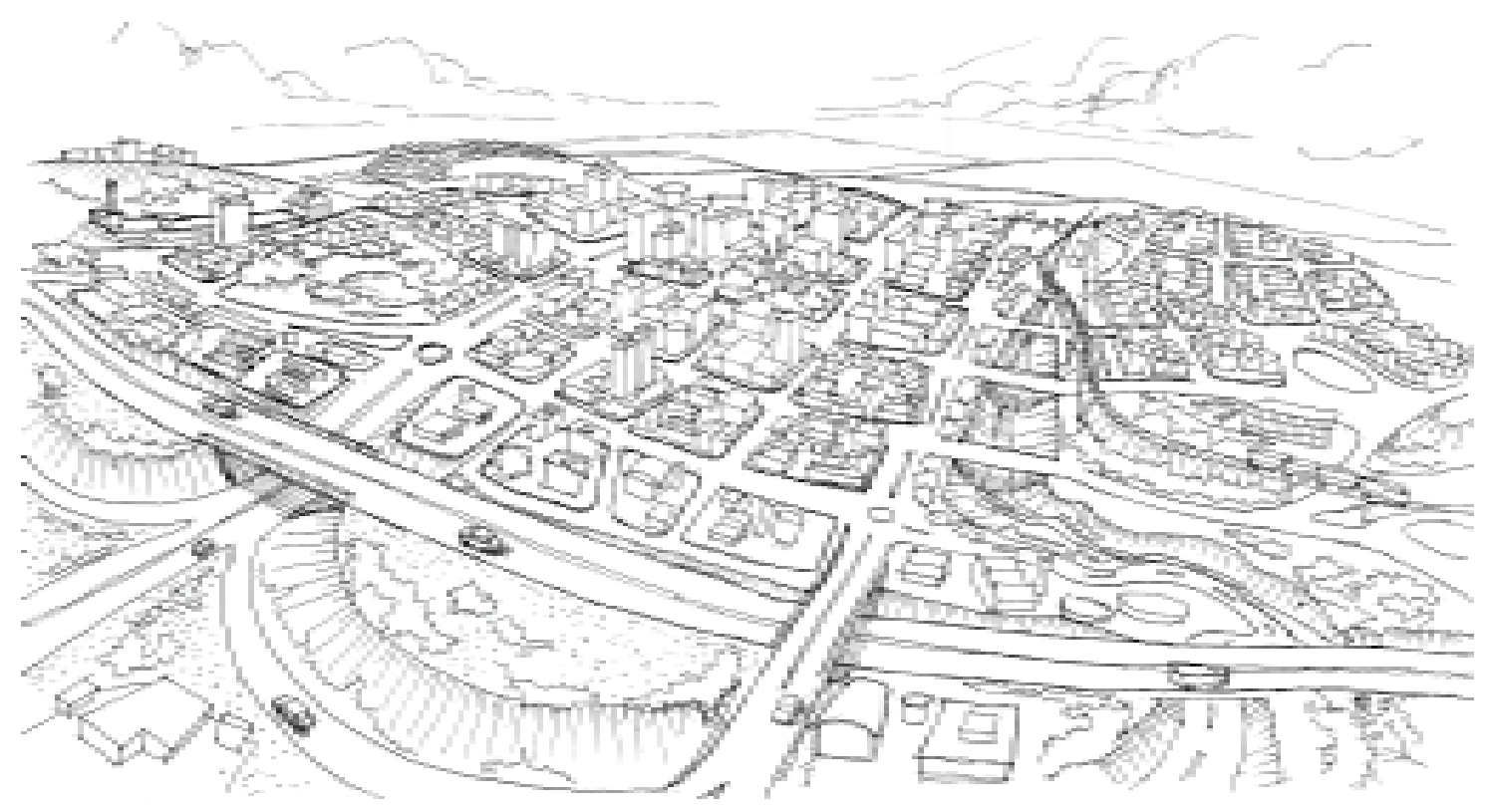

Figura 8E

Crédito: Fornecida pela autora

Tem-se que sua estrutura espacial pode ser subdividida basicamente em: malha urbana, tecido urbano e referenciais urbanos. Seus elementos, por suas características e similaridades, eventualmente podem aparecer em mais de um grupo.

Na malha urbana se inclui a estrutura viária propriamente dita e suas articulações. Sobre esta malha formam-se diferentes tipos de tecido urbano, constituído por volumetrias construídas e plantas similares, destinadas a uso específico, e espaços livres de diferentes funções.

O tecido urbano é subdividido em tecido convencional no qual está incluída a área central, o centro expandido, a área habitacional 
central e o casario convencional, em uma espacialização concêntrica, "tecido jardim", constituído dos "bairros-jardins" e dos condomínios fechados, na periferia urbana, e tecido habitacional popular que diz respeito aos conjuntos habitacionais, tanto os unifamiliares como os verticais e os não-institucionais, e ainda o casario popular. Situados na periferia da mancha urbana, muitas vezes além das barreiras construídas, principalmente rodovias, e geralmente desarticulados do tecido urbano original, justamente pela localização, que impede esta articulação. E ainda a área verticalizada, o campus universitário, o distrito industrial, e os cemitérios, fragmentos de tecido urbano, que também funcionam como marco referencial.

Os referenciais urbanos podem ser construções significativas e de algum destaque, seja pela dimensão, pelo uso ou por ambos, ou estruturas urbanas e/ou trechos do tecido urbano que funcionam como marco dentro da paisagem.

Entendeu-se por construções significativas as instalações ferroviárias, os colégios tradicionais, o centro cultural e/ou teatro, os clubes, os ginásios esportivos, o terminal rodoviário, o aeroporto, os shopping centers e/ou entrepostos comerciais. As construções significativas não apresentam uma tipologia arquitetônica semelhante; entretanto, obedecem a uma localização similar.

As estruturas urbanas, neste caso entendidas por aquelas que funcionam como referenciais e/ou marco na paisagem: a rua principal de comércio, a praça principal, os parques urbanos e/ou grandes massas de vegetação, as avenidas de acesso, os centros de bairro, a avenida com atrações noturnas, as rodovias e/ou anel viário e os cursos e/ou corpos d'água.

A homogeneidade da paisagem urbana das cidades de porte médio do interior central do estado de São Paulo pode, então, ser compreendida a partir de dois componentes: seus determinantes locais, fundamentados nas origens semelhantes destas, e as atuais aspirações da população, induzidas pelos padrões das grandes cidades, considerados representantes de um status civilizado e moderno.

A abordagem é morfológica, em que as questões pertinentes à urbanização e aos aspectos socioeconômicos aparecem como subsídios. A idéia principal é a discussão da cidade do cotidiano, o lado da paisagem urbana, no qual a similaridade morfológica na paisagem da cidade de porte médio do interior é evidente, principalmente por tratarse de cidades com origem e formação similar e onde, paralelamente, o sítio natural não apresenta grandes particularidades. 
Os elementos ditos excepcionais de suas paisagens são os mesmos que identificam morfologicamente trechos importantes das grandes cidades, verdadeiros ícones funcionais e paisagísticos, e que devido à sua adequação ao perfil sociofuncional das cidades em questão, reproduzem-se com os mesmos critérios locais e formais pelo interior paulista.

Podem ser considerados como tais os shopping centers, centros culturais, rodoviárias e até mesmo as áreas verticalizadas, nestas urbes, restritas a trechos-padrão, como áreas centrais e suas vizinhanças. Estes marcos se contrapõem à homogeneidade do casario, reforçando formalmente os padrões de similaridade. A reprodução de modelos de uso e organização do espaço está associado a um conceito cultural de valor (estético e de uso do espaço urbano).

A influência social, cultural e econômica se reflete na organização do espaço urbano, e devido a estes reflexos dominantes, reproduzem-se, até com certo sucesso, os elementos presentes nas paisagens dos centros com maior influência. Assim as imagens formais das grandes cidades são claramente representadas de um modo específico na paisagem urbana das cidades médias, estabelecendo os reflexos formais e funcionais das paisagens dos grandes centros sobre a paisagem das cidades do interior, gerando um valor relacionado aos seus aspectos formais e visuais, em que neste processo de influência é claramente representado na paisagem urbana das cidades interioranas paulistas. Estas cidades incorporam valores que sintetizam padrões qualitativos da cidade brasileira, na qual elementos e estruturas dos grandes centros estão presentes, ainda que organizados de uma maneira mais simples e com um porte menor.

A relativa facilidade encontrada na substituição de elementos originais de épocas passadas se deve principalmente à inexistência de características marcantes destes elementos na paisagem, tornado-os facilmente descartáveis e substituíveis por outras estruturas advindas dos centros de dominação sociocultural e, portanto, pelas novas formas de representação dos valores socioeconômicos vigentes em outros centros maiores, tanto nacionais como internacionais, pois de acordo com Santos (1999):

"A cada novo momento, impõe-se captar o que é mais característico do novo sistema de objetos e do novo sistema de ações. Os conjuntos formados por objetos novos e ações novas tendem a ser mais produtivos e 
constituem, num dado lugar, situações hegemônicas. Os novos sistemas de objetos põem-se à disposição das forças sociais mais poderosas, quando não são deliberadamente produzidos para o seu exercício." (p. 78)

A cidade de São Paulo, um dos grandes referenciais, e geradora de padrões urbanísticos brasileiros, é a síntese de um processo socioeconômico geral do país, que se representa formalmente em escalas diversas nos grandes centros e nas cidades de porte médio. No caso das cidades do interior do estado de São Paulo, este processo de influência da paisagem urbana se estrutura a partir da paisagem que se configura na cidade de São Paulo, e de cidades do porte de Campinas e/ou Ribeirão Preto, as quais por sua vez se referenciam, por exemplo: os novos padrões de uso do solo, como os condomínios fechados e a verticalização, o tratamento das áreas públicas de edificação, como o padrão de arborização e jardinagem urbana, as tipologias arquitetônicas, o desenho de pisos e calçamentos, e ainda pela arquitetura símbolo de edifícios, tais como redes de lojas e instituições financeiras, entre outras.

Estes novos elementos se constituem em representações de uma influência cultural, que indica "modernidades formais", uma representação de estruturas do poder, e assim sendo as manifestações locais tendem a tomá-las como modelo, realimentando o ciclo da homogeneização da paisagem, levando a não-caracterização da paisagem por meio de uma homogeneização formal por intermédio de um processo contínuo de formas importadas, caracterizado pela reprodução de ícones espaciais e arquitetônicos exógenos.

Estes elementos estão presentes no repertório formal criado a partir de viagens feitas aos centros dos quais emanam estes valores, dos manuais e revistas de construção civil e ainda dos padrões determinados pelo mercado imobiliário, como ilustram as Figuras 9A e 9B.

Esta homogeneização formal urbana não conduz necessariamente a situações de degradação ou de baixa qualidade de vida, pois, "a forma física não é a variável fundamental cuja manipulação deverá provocar a mudança. O nosso cenário físico é um resultado direto do gênero de sociedade em que vivemos". (Lynch, 1999, p. 101) A questão está, entretanto, na extrema centralização e padronização de soluções urbanísticas e arquitetônicas adotadas, tanto pelo poder público quanto pela iniciativa privada, que simplesmente adotam e 

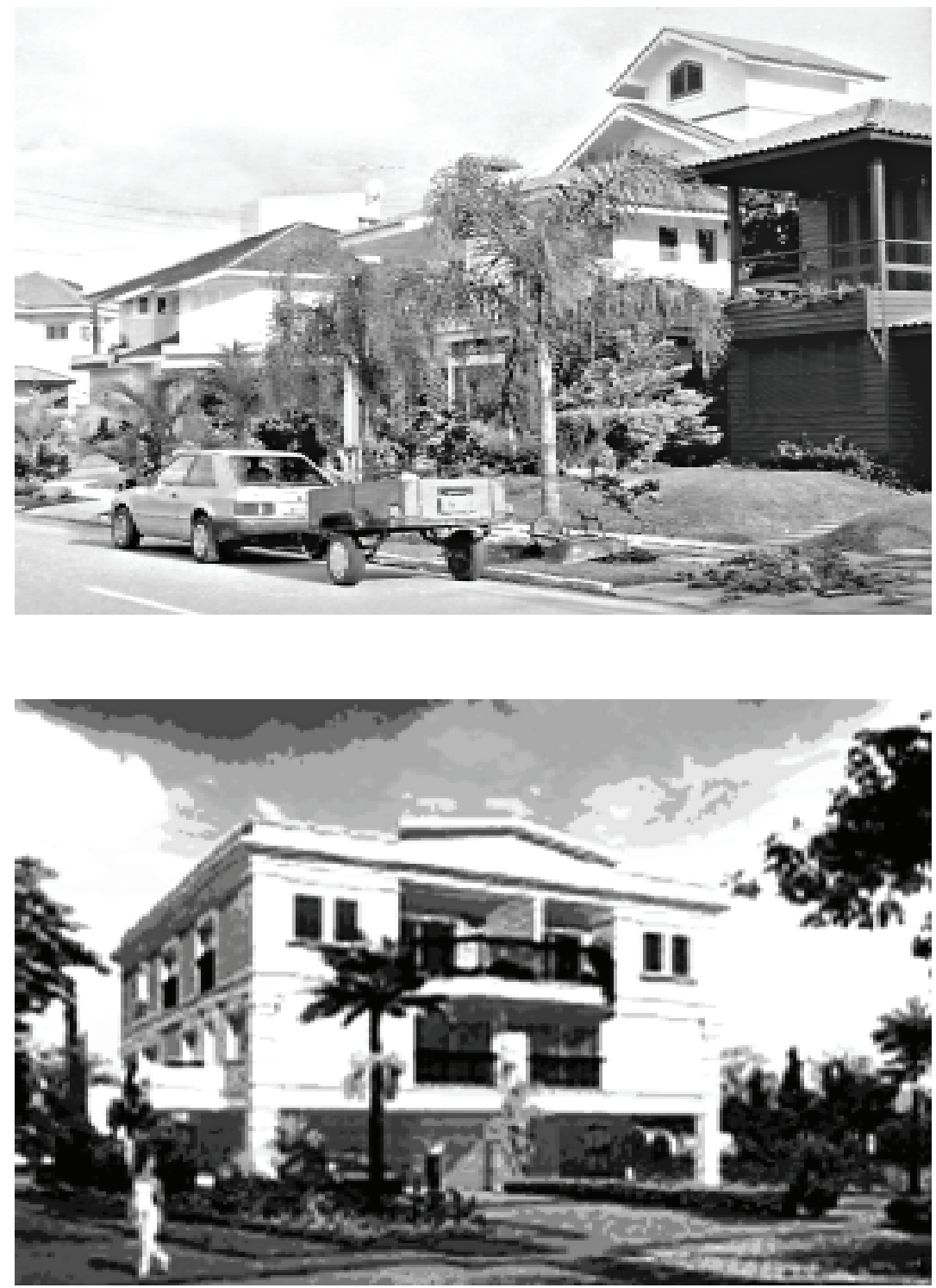

sobrepõem aos mais diversos tipos de paisagens e ambientes, padrões urbanísticos e arquitetônicos estereotipados, eximindo-se de propor outras soluções mais próprias às realidades locais, correndo o risco de incorrerem nos mesmos erros praticados nos grandes centros, nos quais a crise paisagística-ambiental é um fato. Adotam-se, por exemplo, padrões urbanísticos de zoneamento para áreas verticalizadas, menos rígidos que na cidade de São Paulo, que conta com restrições até avançadas, mas ainda insuficientes.

124 Ospaço urbano é, desta forma, construído a partir de generalizações técnicas, que desrespeitam, desconsideram outras possíveis soluções mais adequadas às características locais. A qualidade
Figura 9A - Bairro residencial de classe média alta, em Florianópolis, SC. Os padrões arquitetônicos aqui presentes fornecem o repertório formal, sendo que, por sua vez, também são cópias de elementos encontrados em outros centros, em um processo de retroalimentação Crédito: Autora

Figura 9B - llustração de propaganda imobiliária, notar a similaridade dos padrões fornecidos pelo mercado imobiliário

Fonte: O Estado de S. Paulo 
urbana se perde com legislações malfeitas, como a importação de ícones, e com o fato de a perda de oportunidade de identidade própria não ser uma questão em discussão.

Existe, então, um balizamento formal urbano por padrões altamente genéricos, e mais simplificados, que não representam de fato as condições urbanísticas viáveis de implementação em cada núcleo. $\bigcirc$ que ocorre é uma reprodução dos espaços da classe dominante, ainda que em dimensões reduzidas, reforçando os arquétipos sociais e os modelos de dominação.

Na tentativa de alcançar um grau de satisfação pertencente às elites, até como forma de aspiração social, já que não pertencem à classe dominante, as classes médias em especial, que nessas cidades se constituem em um segmento importante da população urbana, copiam ao menos seu repertório formal.

Paralelamente, a adoção de planos e normas urbanísticas que fortalecem e ratificam o surgimento de formas urbanas não-necessárias, como a já citada verticalização, fortalecem o processo de cópia, que é gerenciado em grande parte pelo mercado imobiliário.

Porém, ao se copiar a forma sem seu contexto, surgem soluções inadequadas em relação à morfologia do relevo, ao clima local e ainda à criação de uma estética desvinculada do comportamento local, cotidiano. Essa prática, ao mesmo tempo em que não possibilita que se atinja o ideal de aspiração social, também impede a experimentação de soluções mais específicas a cada caso.

Um paradigma projetual urbano adotado é um arquétipo da rua e da casa característica do bairro-jardim paulistano, arborizado, com edificações isoladas no lote, traçado sinuoso, nem sempre adotado nas cidades médias do interior central paulista. Este padrão simplificado é adotado sem reflexão sobre as particularidades de uso, clima e de forma das variadas áreas urbanas, sendo que este modelo é totalmente respaldado pelas legislações municipais.

Paralelamente se observa a constituição de um casario comum, que abriga as classes média e baixa, reproduzido em miniatura, de uma forma mais acessível, as outras classes sociais.

A classe média, na impossibilidade de adquirir um lote que permita implantação semelhante, permite-se adaptações sobre a malha urbana convencional, dando origem a construções com recuo frontal e ao fundo. 
A legislação que define os padrões de ocupação urbana, os quais por sua vez definem a configuração física da paisagem (nem sempre verificado nos bairros pobres, onde a burla à legislação urbanística é, por vezes, a regra geral), trabalha basicamente o espaço físicoterritorial, alienando-se dos demais componentes da problemática urbana, e, desta forma, as cidades se homogeneízam. Ou seja, existe um baixo discurso urbanístico e o que se faz é generalista, colaborando para a pasteurização.

Assim, ao balizar-se pelos parâmetros das elites, a obrigatoriedade de padrões para a cidade como um todo, mesmo onde estas soluções não tenham as mínimas condições reais de ocorrerem, resulta em uma má qualidade de vida urbana, que irá se refletir na formação da paisagem, haja vista que a paisagem reflete uma realidade determinada por parâmetros vários.

Desde os tempos do Brasil colônia, a classe dominante ditava as regras na produção do espaço urbano. Antes da Independência a normatização vinha de Portugal, como forma de controlar a vida na colônia e reforçar a dependência em relação à metrópole. No século 19 a modernização da cidade é feita por e para as elites, e estendese até os dias de hoje. A legislação sempre refletiu os interesses da classe dominante, sendo para e por ela criada, e direcionou a configuração urbana, e conseqüentemente a formação da paisagem.

A industrialização da Europa e dos Estados Unidos, e posteriormente de outros lugares, na segunda metade do século 19, significou uma grande transformação nas cidades, fazendo com que elas assumissem a forma que ainda hoje se desenvolve, ou seja, "uma pequena classe construiu uma nova paisagem para permitir uma produção mais rentável e uma concentração acumulada de capital", e onde:

"sempre que possível, o trabalho e a residência foram separados por tipo e por classe - em certa medida para melhorar a eficiência, mas especialmente para controlar a ameaça da violência e da doença, e para afastar dos olhares da classe superior a mão-de-obra laboriosa que sustentava os seus rendimentos". (Lynch, 1999, p. 27-30)

Ou ainda, segundo Benevolo (1991):

"A cidade burguesa que se desenvolve depois da revolução industrial é, com certeza, diferente de todo modelo anterior, antes de tudo por seus elementos mensuráveis: 
as quantidades em jogo (número de habitantes, número de casas, quilômetros de estradas, número e variedade dos serviços e das aparelhagens) e a velocidade das transformações; as diversidades quantitativas produzem, somando-se, uma diversidade qualitativa, isto é, tornam impraticáveis os antigos instrumentos de controle, que estão baseados justamente numa limitação conhecida das quantidades e das velocidades, e propiciam o surgimento de novas oportunidades e de novos riscos que só podem ser comparados com novos instrumentos de projeção e de gestão: voltam a propor, por conseguinte, de maneira integral e pela primeira vez depois da Idade Média, o problema do planejamento urbano." (p. 22)

Segundo Macedo (1998), este controle se acentua com as alterações sobre a posse da terra na formação da moderna nação brasileira e as respectivas formas de controle exercidas pelo Estado, representadas principalmente pelo poder municipal, como forma de ordenar as formas de ocupação urbana.

De acordo com Villaça (1998, p. 12), "a estrutura territorial é socialmente produzida e ao mesmo tempo reage sobre o social", ou ainda, segundo Reis Filho (1994 p. 09), "nas obras e nas formas de sua produção e uso, é possível compreender as condições de vida e as etapas de evolução das cidades."

O espaço construído a partir de generalizações técnicas impede e/ou não considera outras soluções mais adequadas às características locais.

A homogeneidade dos padrões morfológicos, no caso em foco a gênese destas cidades está vinculada a ciclos de desenvolvimento semelhantes, tais como a expansão da produção cafeeira no início do século 20 e o conseqüente incremento da rede ferroviária, e posteriormente, o ciclo rodoviário, imprimiram às cidades um padrão de urbanização bastante similar. Segundo Matos ${ }^{2}$, é indiscutível a importância da ferrovia na paisagem urbana das cidades do interior do estado de São Paulo.

Aliado a este fator convém ressaltar que ao repetir nas cidades do interior os elementos formais urbanísticos ou arquitetônicos das cidades de São Paulo ou do Rio de Janeiro, procurou-se uma sintonia com este mesmo poder e/ou uma identidade com a modernidade vigente. Segundo Marx (1980): 
"As peculiaridades destas centenas de aglomerações novas são excepcionais entre nós pela regularidade de conjunto em cada uma. Como Mococa, Matão, Bauru ou Gália, os espigões ou chapadas acomodam ruas em tabuleiro de xadrez e uma sempre presente praça central, a matriz. Paisagem e referência usuais no oeste paulista, que conferem feição marcante monótona, tanto aos estabelecimentos rurais como urbanos." (p. 36)

Paralelamente, diferentemente da cidade de São Paulo, onde ainda podemos encontrar vestígios de um centro histórico, ainda que conurbado, resultante da não-adaptação dos usos atuais àquele espaço de implantação colonial, ou ainda, cidades como o Rio de Janeiro, onde além dos mesmos elementos igualmente presentes em São Paulo, a natureza é parte integrante e significativa da paisagem urbana, nas cidades mencionadas na citação acima a monotonia é reforçada pela falta destes elementos. E ainda, não é possível verificar nessas estruturas urbanas calcadas, em geral, no reticulado xadrez, e projetadas para a escala do automóvel, percursos que despertem a curiosidade para o que acontecerá na próxima esquina.

De fato, essas situações só ocorrem em contextos particulares, como no caso de condomínios fechados, em alguns projetos de praças e parques urbanos, em cidades turísticas e/ou históricas, ou qualquer situação em que o enfoque seja centrado no pedestre e no estar em público, e não área de passagem, como pode ser observado nas Figuras 10A e 10B.

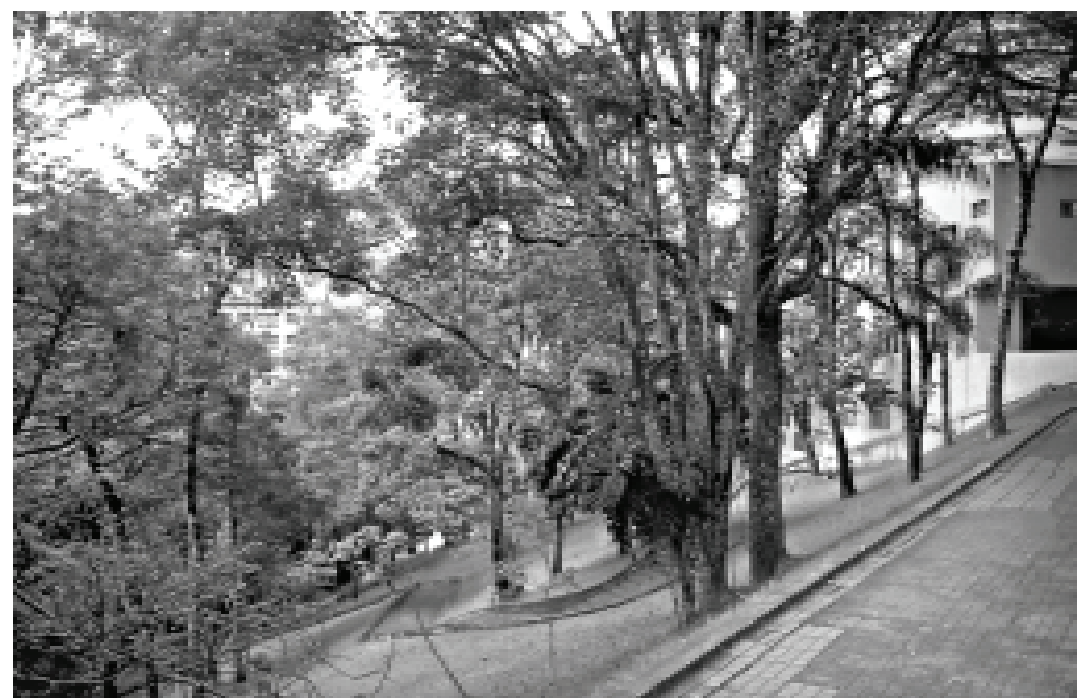

Figura 10A - Águas de Lindóia, SP Crédito: Autora 
Figura 10B - Bauru, SP Crédito: Autora

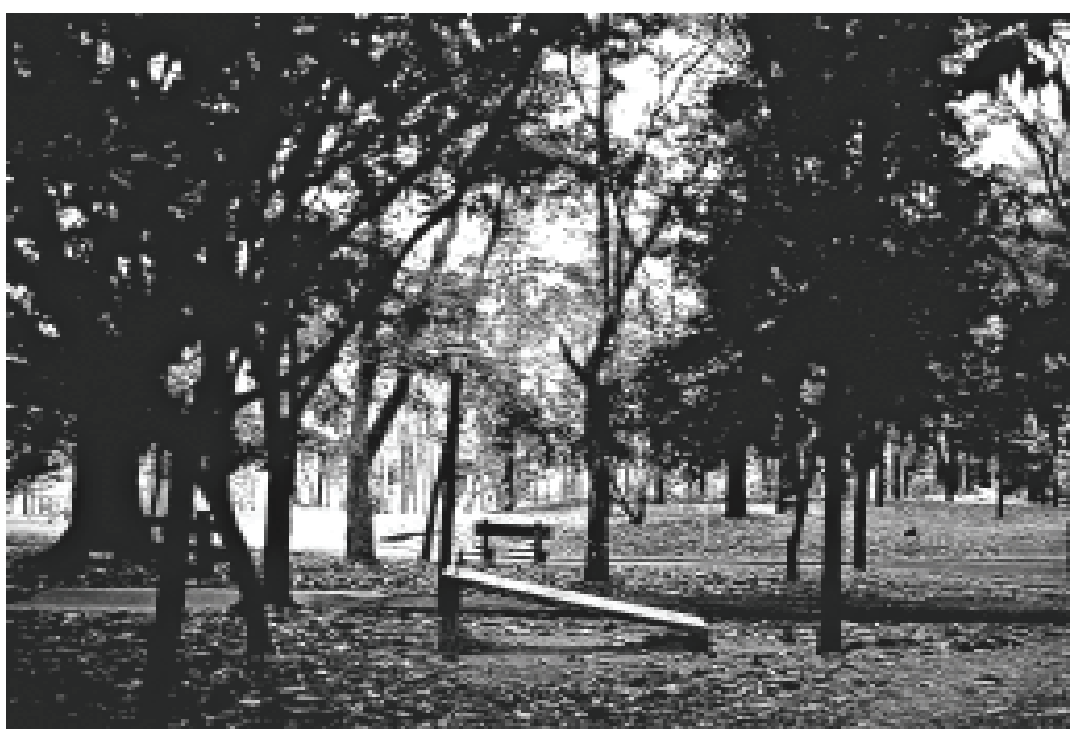

Essa ocorrência pode ser também observada em assentamentos espontâneos, no caso favelas, na qual a organização independe do automóvel.

As paisagens destas cidades de fato nunca apresentaram características particulares significativas, e tampouco isto seria possível, se pensarmos em sua origem comum, e principalmente em sua formação urbana similar.

Em seus agenciamentos originais, o sítio natural não propicia, normalmente, pontos especiais passíveis de destaque, fato que justifica também a falta de identidade própria nestas cidades. Desta forma os elementos originais da paisagem das cidades paulistas são bastante simplificados, podendo-se observar apenas alguma distinção quanto à organização das áreas públicas livres de edificações. Estes elementos originais raramente se apresentam como um elemento configurador da paisagem, não chegando mesmo a constituírem-se em imagens plenas de significado para sua população.

São cidades muitas de origens ferroviárias, outras feitas diretamente pela companhia ferroviária, outras tantas construídas ao longo de rodovias, e que são resultado de um processo de urbanização extensa e homogênea, típica da formação urbana do interior do estado de São Paulo.

Portanto, pode-se afirmar que estes padrões morfológicos fornecem um modelo de paisagem, ao qual está ligado um modelo de qualidade de vida, em que a sociedade passa a valorizar a presença dos elementos globais que estão em sintonia com os centros de poder. 
A paisagem da cidade média do interior central paulista é então homogênea, como conseqüência desta forma de ocupação homogênea, a qual é decorrente de códigos de obras e planos diretores padronizados, bem como ciclos de desenvolvimento semelhantes, o que resulta em padrões de urbanização uniformes, associados a tipologias arquitetônicas e material de acabamento similares.

$\mathrm{Na}$ verdade falta a essas cidades ações de projeto, das quais o desenho urbano é uma delas, visando um projeto urbano de paisagem, uma configuração urbana concebida a partir de uma intenção clara e definida, de um objetivo social, de chegar-se a uma configuração urbana preestabelecida.

E, justamente pela falta de um projeto de ação específico para cada local é que as cidades se configuram a partir da reprodução e/ou adoção de um modelo, o qual por sua vez também reproduz modelos urbanos diversos e comuns, reforçando a lógica da homogeneidade.

Os planos diretores encomendados pelas prefeituras contribuem para essa situação na medida em que copiam e reproduzem os modelos considerados mais avançados e atraentes de uma cidade para a outra. Raramente os planos diretores consideram na extensão devida as condições locais e o impacto ambiental, mesmo porque isso eventualmente prejudicaria sua aprovação pelos poderes constituídos.

Desse modo, a forma urbana é resultante de regras com objetivos altamente genéricos, produto de ações diversas e aleatórias, como, por exemplo, as leis de zoneamento. Isto é, um desenho proveniente das legislações, e não de um projeto. Ou seja, na realidade o que existe são formas urbanas que surgem muito mais de processos generalizantes do que de ações que visam à totalidade.

De fato não existe um projeto urbano nas cidades em geral, quanto menos nas do interior do estado de São Paulo, e sim apenas uma forma urbana, decorrente de ações e regulamentações sem nenhuma intenção de projeto.

A cidade somente pode ser reconhecida por sua paisagem urbana, e esta paisagem é resultante dos elementos econômicos, sociais e culturais que produziram esta cidade em um determinado momento no tempo, na história, em um determinado contexto.

Partindo do pressuposto de que a qualidade formal é a união entre os cidadãos e sua cidade, por meio da criação de mapas mentais, 
o ideal seria que houvesse um investimento na elaboração de soluções urbanísticas que atribuíssem uma identidade visual a estas cidades, reforçando e/ou construindo elementos e espaços que fortalecessem a legibilidade do espaço urbano, pois "uma boa correspondência funcional normalmente significa uma paisagem mais congruente, e freqüentemente (embora nem sempre) uma paisagem mais transparente, mais significativa e mais identificável". (Lynch, 1999, p.141-144)

Como contraposição à paisagem homogênea, o desenvolvimento de valores estéticos a partir de condições culturais, ambientais e paisagísticas locais pode servir como ferramenta para projetos urbanísticos/paisagísticos diferenciados e característicos para cada cidade, obtendo desta forma paisagens urbanas particularizadas, respeitando os referenciais e as especificidades próprias, podendo contribuir para uma melhor qualidade ambiental das cidades.

Ao verificar-se quais são os elementos marcantes que conferem particularidade a estas paisagens, e, reforçando estes elementos por meio de projetos urbanos, poderá obter-se paisagens urbanas respeitando os referenciais e as especificidades locais, contribuindo para uma melhor qualidade ambiental das cidades, pela suspensão da idéia de construção por modismo ou benefícios baixos.

\section{Bibliografia}

AMADOR, Itamar Moraes. As manifestações sociais e econômicas conjugadas com as condições físico-ambientais, determinam a paisagem urbana. Estudo de caso: São Carlos, SP. São Paulo, 1990. Tese ( Doutorado) - Faculdade de Arquitetura e Urbanismo, Universidade de São Paulo.

BAPTISTA, Maria Rosa de Belém. Rio Claro: As pedras da cidade. São Paulo, 1994. Dissertação (Mestrado) - Faculdade de Filosofia, Letras e Ciências Humanas, Universidade de São Paulo.

BENEVOLO, Leonardo. A cidade e o arquiteto. São Paulo: Perspectiva, 1991.

CULLEN, Gordon. Paisagem urbana. São Paulo: Martins Fontes, 1988.

DEÁK, Csaba, SCHIFFER, Sueli Ramos. (Org.) O processo de urbanização no Brasil. São Paulo: Edusp, 1999.

DEL RIO, Vicente. Introdução ao desenho urbano. São Paulo: Pini, 1990. 
GHIRARDELLO, Nilson. Aspectos do direcionamento urbano da cidade de Bauru. São Carlos, 1992. Dissertação (Mestrado) - Escola de Engenharia de São Carlos, Universidade de São Paulo.

. À beira da linha: Formações urbanas da Noroeste Paulista. São Paulo, 1999. Tese (Doutorado) - Faculdade de Arquitetura e Urbanismo, Universidade de São Paulo.

HIRAO, Hélio. Rua e pedestres: O planejamento visual urbano dos projetos públicos adequados ao contexto regional: $O$ caso de Presidente Prudente. São Paulo, 1990. Dissertação (Mestrado) - Faculdade de Arquitetura e Urbanismo, Universidade de São Paulo.

KOHLSDORF, Maria Elaine. A apreensão da forma da cidade. Brasília: Editora Universidade de Brasília, 1996.

. Percepção da paisagem e planejamento da identidade. Caderno Paisagem. Paisagens. Rio Claro, Unesp, n. 3, 1998.

LANDIM, Paula da Cruz. Desenho de paisagem urbana: As cidades do interior paulista. São Paulo, 2001. Tese (Doutorado) - Faculdade de Arquitetura e Urbanismo, Universidade de São Paulo.

LEITE, Carlos. Kevin Lynch. Imagem e desenho das cidades. Projeto Design, São Paulo, Arco, mar. 1998.

LYNCH, Kevin. A imagem da cidade. São Paulo: Martins Fontes, 1982.

. A boa forma da cidade. Lisboa: Edições 70, 1999.

MACEDO, Silvio Soares. Espaços livres. Paisagem, Ambiente e Ensaios. São Paulo, FAUUSP, n. 7, 1995.

Paisagem, configuração e formação - questões envolvendo legislação. Cadernos Paisagem. Paisagens. Rio Claro, Unesp, n. 3, 1998.

MACHADO, Lucy M. C. Philadelpho. Qualidade ambiental urbana: Percepções e estratégias para uma cidade de porte médio. Rio Claro: Departamento de Geografia, IGCE, Unesp, 1993.

MARX, Murilo. Cidade brasileira. São Paulo: Melhoramentos, 1980.

MATOS, Odilon Nogueira de. Café e ferrovia. São Paulo: Edições Arquivo do Estado. Coleção Monografia, 1981.

MUMFORD, Lewis. A cidade na história. Belo Horizonte: Itatiaia, 1965.

PADOVANO, Bruno R. Legibilidade da paisagem urbana: O caso de Santo Amaro. São Paulo, 1987. Tese (Doutorado) - Faculdade de Arquitetura e Urbanismo, Universidade de São Paulo.

PEREIRA LEITE, Maria Angela F. Destruição ou deconstrução? São Paulo: Hucitec, 1994.

PREFEITURA MUNICIPAL DE BAURU. Plano diretor de desenvolvimento integrado. Bauru: Prefeitura Municipal de São Paulo, 1996.

132 REIS FILHO, Nestor Goulart. Quadro da arquitetura no Brasil. São Paulo: Perspectiva, 1970. 
REIS FILHO, Nestor Goulart. São Paulo e outras cidades. São Paulo: Hucitec, 1994.

RELPH, Edward. A paisagem urbana moderna. Lisboa: Edições 70, 1990.

SANTOS, Milton. Metamorfoses do espaço habitado. São Paulo: Hucitec, 1991. Técnica, espaço e tempo. São Paulo: Hucitec, 1994. A natureza do espaço. São Paulo: Hucitec, 1999.

TURKIENICZ, Benamy (Org.). Desenho UrbanoI "I Seminário sobre Desenho Urbano no Brasil". Cadernos Brasileiros de Arquitetura 12. São Paulo: Projeto, 1984.

Desenho Urbano II "I Seminário sobre Desenho Urbano no Brasil". Cadernos Brasileiros de Arquitetura 13. São Paulo: Projeto, 1984.

Desenho Urbano III "I Seminário sobre Desenho Urbano no Brasil". Cadernos Brasileiros de Arquitetura 14. São Paulo: Projeto, 1984.

VENTURI, Robert et al. Aprendiendo de Las Vegas. Barcelona: Gustavo Gilli, 1978.

VILLAÇA, Flávio. Espaço intra-urbano no Brasil. São Paulo: Nobel/ Fapesp, 1998. 